\title{
Correction to: Staphylococcus aureus and Its Proteins
}

\author{
Goran Abdurrahman and Barbara M. Bröker
}

\section{Correction to: Chapter 14 in: L. Zhang, C. Bachert (eds.), Chronic Rhinosinusitis, https://doi.org/10.1007/978-981-16-0784-4_14}

The book was inadvertently published with the error in the name and affiliation of Goran Abdurrahman and has been updated as below:

The author name Goran Abdurrahmanm has been changed to Goran Abdurrahman.

In the affiliation of Goran Abdurrahman, the "Department of Immunology" has been changed to "Institute of Immunology". 